\title{
Tracking of energy and nutrient intakes from adolescence to young adulthood: the experiences of the Young Hearts Project, Northern Ireland
}

\author{
AM Gallagher 1,*, PJ Robson ', MBE Livingstone ${ }^{1}$, GW Cran ${ }^{2}$, JJ Strain ${ }^{1}$, LJ Murray ${ }^{2}$, \\ JM Savage ${ }^{3}$ and CAG Boreham ${ }^{4}$ \\ ${ }^{1}$ Northern Ireland Centre for Food and Health (NICHE), University of Ulster, Coleraine BT52 1SA, UK: ${ }^{2}$ Department \\ of Epidemiology and Public Health, The Queen's University of Belfast, Institute of Clinical Science, Belfast BT12 6BJ, \\ UK: ${ }^{3}$ Department of Child Health, The Queen's University of Belfast, Clinical Institute, Royal Victoria Hospital, Belfast \\ BT12 6BJ, UK: ${ }^{4}$ School of Leisure and Tourism, University of Ulster, Jordanstown BT37 OQB, UK
}

Submitted 8 December 2004: Accepted 18 May 2005

\begin{abstract}
Objective: To assess tracking of energy and nutrient intakes between adolescence and young adulthood.

Design: Longitudinal study of a random sample of adolescents (aged 15 years at baseline). The extent of tracking of dietary intakes (assessed by diet history) was investigated using weighted kappa statistics $(\boldsymbol{\kappa})$.

Setting: Northern Ireland population survey.

Subjects: Adolescents who participated in the Young Hearts Project, Northern Ireland at age 15 years, and subsequently at young adulthood aged between 20 and 25 years ( $n=245$ males, $n=231$ females).

Results: Despite overall increases in height and weight (both $P<0.001$ ), increases in body mass index in males $(P<0.001)$ and body fatness in females $(P<0.001)$, median reported intakes of energy $\left(\mathrm{kJ} \mathrm{kg}^{-1} \mathrm{day}^{-1}\right)$, carbohydrate $\left(\mathrm{g} \mathrm{day}^{-1}\right)$ and fat $\left(\mathrm{g} \mathrm{day}^{-1}\right.$ ) decreased (all $P<0.001$ ) over time. Expressed as nutrient densities (per $\mathrm{MJ})$, diets at young adulthood were overall richer in thiamin, vitamin $\mathrm{B}_{6}$, total folate (all $P<0.001)$, vitamin C $(P<0.01)$ and vitamin D $(P<0.05)$. Whereas the nutrient density of the males' diets decreased over time for calcium $(P<0.05)$ and vitamin A $(P<0.001)$, iron and riboflavin densities increased in the females' diet $(P<0.001)$. Tracking of energy $\left(\mathrm{MJ} \mathrm{day}^{-1}\right)$ and nutrient intakes (expressed per MJ day ${ }^{-1}$ ) at the individual level was only poor to fair (all $\kappa<0.25$ ), indicating substantial drift of subjects between the low, medium and high classes of intake with increasing age. Conclusions: These data suggest that individual dietary patterns exhibited at 15 years of age are unlikely to be predictive of dietary intakes at young adulthood.
\end{abstract}

\author{
Keywords \\ Nutrient density \\ Nutrient intake tracking \\ Young Hearts Project \\ Northern Ireland \\ Adolescence \\ Young adulthood
}

Tracking has been defined as the maintenance of relative position in rank of behaviour over time $e^{1,2}$. Only a limited number of longitudinal studies have investigated the extent of tracking of nutrient intakes from adolescence into young adulthood and the results have been inconsistent. Cusatis et $\mathrm{al}^{3}{ }^{3}$ concluded that nutrient intake patterns did not track strongly during adolescence (between 12 and 18 years). Post et al. $^{4}$ investigated the extent of tracking of nutrient intakes between 13 and 33 years of age in the Amsterdam Growth and Health Longitudinal Study. Significant stability coefficients for all nutrients were found (0.28-0.52); however, over the entire study period (between ages 13 and 33 years) the authors concluded that dietary intake between adolescence and adulthood was changeable ${ }^{4}$. Dunn et $a l^{5}$ observed a poor to moderate correlation for most nutrient intakes reported by subjects aged 18-30 years over a 7year period but concluded that, despite considerable changes in lifestyle, individuals tend to remain within broad categories of intake.

Previous work in the Northern Ireland Young Hearts cohort $^{6}$ demonstrated poor tracking of energy and nutrient intakes in subjects assessed at age 12 years and again at age 15 years. More recently, follow-up data have been collected in this cohort at age $20-25$ years ${ }^{7}$. Adolescence is a period of life when food and nutrient intakes can fluctuate owing to erratic eating behaviour. However, it could be speculated that towards the end of the adolescent period eating patterns may stabilise. Thus the aim of the present study was to evaluate the extent to which patterns in dietary intakes in these subjects track from age 15 years through to young adulthood (20-25 years). 


\section{Methodology}

\section{Subjects}

The Young Hearts Project is an ongoing study of biological and behavioural risk factors for cardiovascular disease in a representative sample of young people from Northern Ireland. The baseline survey (YH1) was completed in 1990 on a randomly selected sample of schoolchildren from Northern Ireland ( $n=1015 ; 251$ 12-year-old males, 258 12-year-old females, 252 15-year-old males and 254 15year-old females). The original group of 12-year-olds (then aged 15 years) was followed up in 1992/93 (YH2) with complete data collected on 225 males and 230 females, representing a 90\% response rate. Further details of the study design and sampling procedure used for YH1 and YH2 are reported elsewhere ${ }^{8}$. Between October 1997 and October 1999, all of the original participants in the Young Hearts Project were invited to participate in the third examination phase (YH3). In this phase of the study a $48.2 \%$ response rate (251 males and 238 females) was achieved $^{7}$. Figure 1 shows the numbers of subjects participating in each sampling phase of the study. The present study is based on data obtained from participants at age 15 years and subsequently at young adulthood (YH3) ( $n=245$ males, $n=231$ females). Ethical approval was obtained from the Medical Research Ethical Committee of The Queen's University of Belfast and written informed consent was obtained from parents or guardians (at YH1 and YH2 only) and from all participating subjects at all time points.

\section{Antbropometry}

In all phases of the study, measurements of height, weight and skinfold thicknesses were made. Subjects, wearing light indoor clothing and no shoes, were weighed to the nearest $0.1 \mathrm{~kg}$ using scales; height was measured to the nearest millimetre using a freestanding, portable stadiometer. Body mass index (BMI) was computed as weight $(\mathrm{kg}) /[\text { height }(\mathrm{m})]^{2}$. Skinfold thicknesses were measured in duplicate using standardised procedures to the nearest millimetre using callipers at four sites (biceps, triceps, subscapular and suprailiac) and used to estimate body fatness ${ }^{9}$. Maturational stage was assessed using the Tanner index of pubertal development (YH1 and YH2 only) ${ }^{10}$.

\section{Dietary intakes}

The diet history method with open-ended interview ${ }^{11}$ was used to record the usual weekly meal and snack intake of each subject at both time points, i.e. at age 15 years $^{12}$ and in the present study ${ }^{7}$. Interviews were conducted in a oneto-one setting by trained fieldworkers. The number of interviews conducted by each fieldworker was approximately equal for each age-sex group. A standardised form was used to record meals and snacks, portion size and frequency of eating. Information was obtained on the usual meal and snack pattern of the subject, including place of consumption; usual foods consumed during the week and on weekends; and detailed description of these foods including methods of preparation and portion size. After the usual eating pattern had been described, a review of the information was obtained with particular emphasis on probing for foods that had not been mentioned. Amounts of foods and fluids consumed were estimated by means of photographs of known portion weights of foods supplemented with the use of common household cups, glasses and dishes. Energy and nutrient intakes were calculated using computerised databases as previously described $^{7,12}$. The basal metabolic rate of each subject was estimated $\left(\mathrm{BMR}_{\mathrm{est}}\right)$ using appropriate equations based on sex, height and weight ${ }^{13}$. The same methods were used to

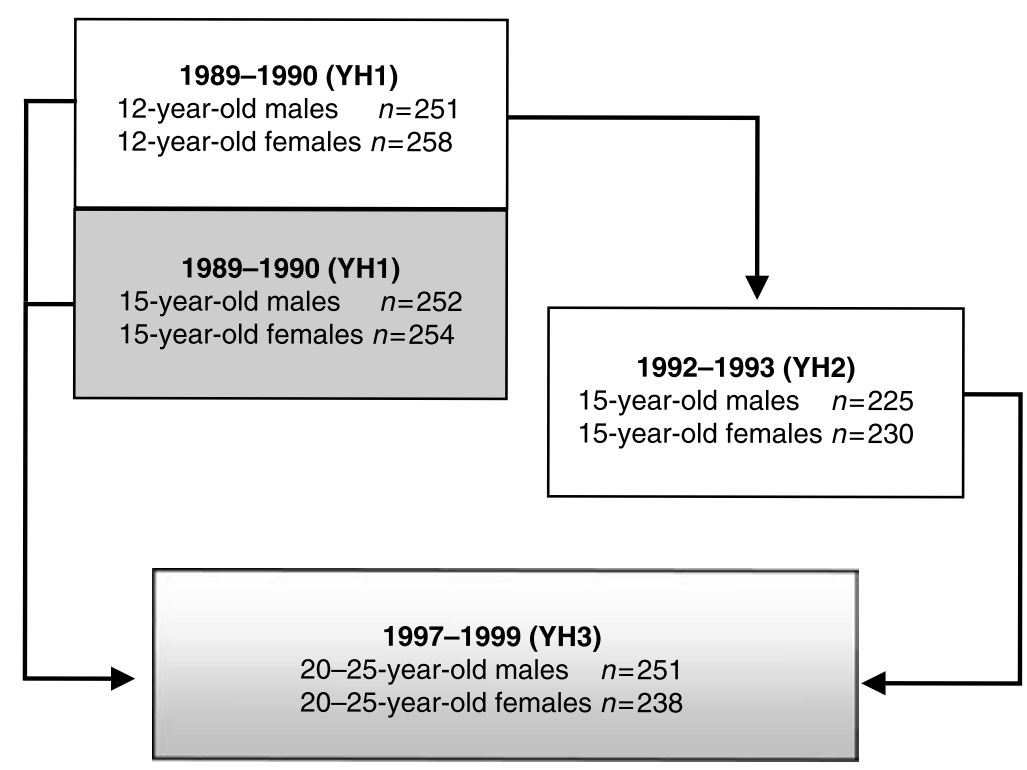

Fig. 1 Numbers of subjects participating in each phase of the Young Hearts (YH) Project, Northern Ireland 
Tracking of intakes from adolescence to young adulthood

assess anthropometric status and dietary intake at all sampling time points (i.e. at age 15 years and at young adulthood).

\section{Statistical analyses}

In an earlier paper $^{12}$, the advantages of using percentiles, rather than the mean and standard deviation (SD), to describe dietary intakes were outlined. Consequently, to maintain consistency in the present study, dietary data are summarised as medians, with the 25th and 75 th percentiles included as a measure of variation. These percentiles are also used to describe body composition data. The Wilcoxon matched-pairs signed-ranks test was used to test that the median of the population of paired differences of adolescent and young adulthood values is zero at a $5 \%$ significance level.

In the present study, daily energy or nutrient intake was considered to track well over time if subjects with 'low', 'medium' or 'high' intakes at adolescence (at age 15 years) maintained their ranking at young adulthood. This method, based on ranks, is described in detail elsewhere ${ }^{6}$. In brief, in order to study the tracking of energy intake (EI) of males from adolescence to young adulthood, the group of males aged 15 years $(n=245)$ was divided into tertiles according to EI: lowest tertile (L1), middle tertile (M1) and highest tertile (H1). Similarly at young adulthood, the group was divided into three tertile classes: L2, M2 and H2. Using these two classifications, a $3 \times 3$ tracking matrix was constructed, the entry in a specific cell being the number of subjects belonging to the corresponding classes at adolescence and at young adulthood. The resulting matrix provides a broad picture of the relative changes in intake of the group over the period. The degree of tracking was summarised by a linear weighted kappa value $(\kappa)^{14}$ calculated from the matrix; $\kappa=1$ when the degree of tracking is perfect, i.e. when every subject maintained their tertile position at adolescence and at young adulthood. Guidelines for interpretation of the value of $\kappa$ obtained have been defined as follows ${ }^{14}:<0.20$, poor; 0.21-0.40, fair; 0.41-0.60, moderate; 0.61-0.8, good; $0.81-1.0$, very good. In addition, $95 \%$ confidence limits for $\kappa$ were calculated. This procedure was undertaken for intakes of energy, macronutrients and selected micronutrients.

\section{Results}

The physical characteristics, reported EI and macronutrient intakes of the Young Hearts cohort at age 15 years (mean age 15.5 (SD 0.13) and 15.6 (SD 0.11) years for males and females, respectively) and at young adulthood (mean age 22.4 (SD 1.61) and 22.8 (SD 1.66) years for males and females, respectively) are presented in Table 1. Body weight and height of both males and females increased significantly $(P<0.001)$ during this period. At age 15 years, median weights of both males and females

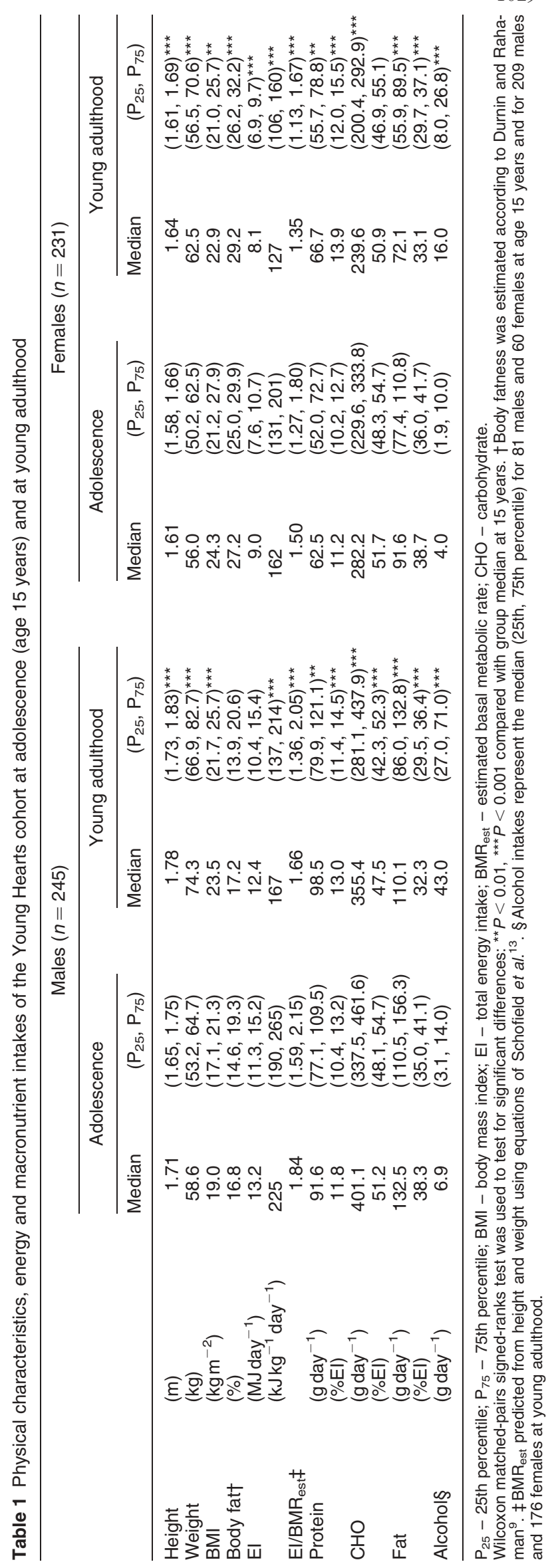


were greater than the median weights for the equivalent UK populations ${ }^{15}$ (by $3.7 \%$ and $6.7 \%$ for males and females, respectively). Similarly at young adulthood, median weights were greater by $6.1 \%$ in males and $6.8 \%$ in females than the median weights for the equivalent UK population $^{15}$. BMI of males increased significantly $(P<0.001)$ but decreased for females over the same period $(P<0.01)$. Conversely, body fatness of males did not alter substantially during the study period whereas it increased in females by $7.4 \%$ in relative terms $(P<0.001)$.

Despite increases in weight, height and BMI, median EI $\left(\mathrm{MJ} \mathrm{day}^{-1}\right.$ ) reported by the males decreased by $7 \%$ over time. Although weight, height and percentage body fatness increased during this period in the females, reported median EI $\left(\mathrm{MJ} \mathrm{day}^{-1}\right)$ at young adulthood was significantly lower $(10 \%)$ than at age 15 years $(P<0.001)$. Expressed relative to body weight $\left(\mathrm{kJ} \mathrm{kg}^{-1}\right.$ day $\left.{ }^{-1}\right)$, EI reported by males and females was significantly lower at young adulthood than at age 15 years $(P<0.001$, both sexes). The ratio of total EI to predicted BMR (EI/BMR est $)$ also decreased significantly over time in both groups $(P<0.001$, both sexes) and may reflect an increase in levels of underreported EI with age within the cohort. In contrast to decreases in carbohydrate (CHO) and fat intakes, protein intakes (expressed as $\mathrm{gday}^{-1}$ or as percentage contribution to $\mathrm{EI}, \% \mathrm{EI}$ ) increased during the same period (both sexes, $P<0.01$ ). At young adulthood, both the number of subjects reporting alcohol consumption and the levels of alcohol intake by alcohol consumers were significantly increased compared with those at age 15 years $(P<0.001$, both sexes).

The weighted $\kappa$ values for EI and macronutrients are given in Table 2. The tracking of EI and macronutrient intakes at the individual level was only poor to fair. A fair degree of tracking was found over the study period for EI $\left(\mathrm{kJ} \mathrm{kg}^{-1}\right.$ day $^{-1} ; \kappa=0.26$ and 0.33 for males and females, respectively). With the exception of protein intakes in females $\left(\mathrm{g} \mathrm{day}^{-1} ; \kappa=0.25\right.$, fair tracking), the tracking of macronutrients (expressed as $\mathrm{g} \mathrm{day}^{-1}$ or \%EI) from adolescence to young adulthood was poor $(\kappa<0.20)$.

Table 2 Tracking of energy and macronutrient intakes as estimated by weighted kappa values $(\kappa)$

\begin{tabular}{|c|c|c|c|c|c|}
\hline & & \multicolumn{2}{|c|}{$\begin{array}{c}\text { Males } \\
(n=245)\end{array}$} & \multicolumn{2}{|c|}{$\begin{array}{l}\text { Females } \\
(n=231)\end{array}$} \\
\hline & & к & (95\% Cl) & $\kappa$ & (95\% Cl) \\
\hline \multirow[t]{2}{*}{ El } & $\left(\mathrm{MJ} \mathrm{day}^{-1}\right)$ & 0.20 & $(0.09,0.30)$ & 0.21 & $(0.11,0.31)$ \\
\hline & $\left(\mathrm{kJ} \mathrm{kg}^{-1}\right.$ day $\left.^{-1}\right)$ & 0.26 & $(0.17,0.36)$ & 0.33 & $(0.23,0.43)$ \\
\hline \multirow[t]{2}{*}{ Protein } & $\left(\mathrm{gday}^{-1}\right)$ & 0.11 & $(0.01,0.21)$ & 0.25 & $(0.15,0.35)$ \\
\hline & (\%EI) & 0.11 & $(0.01,0.21)$ & 0.20 & $(0.10,0.30)$ \\
\hline \multirow[t]{2}{*}{$\mathrm{CHO}$} & $\left(\mathrm{g} \mathrm{day}^{-1}\right)$ & 0.12 & $(0.02,0.22)$ & 0.18 & $(0.08,0.28)$ \\
\hline & (\%EI) & 0.13 & $(0.03,0.23)$ & 0.11 & $(0.01,0.21)$ \\
\hline \multirow[t]{2}{*}{ Fat } & $\left(\right.$ g day $\left.^{-1}\right)$ & 0.15 & $(0.05,0.25)$ & 0.18 & $(0.08,0.29)$ \\
\hline & $(\% \mathrm{El})$ & 0.13 & $(0.02,0.23)$ & 0.16 & $(0.06,0.26)$ \\
\hline
\end{tabular}

$\mathrm{Cl}$ - confidence interval; $\mathrm{El}$ - total energy intake, $\mathrm{CHO}$ - carbohydrate. $\kappa$ values were calculated as described in the Methodology; standard errors for $\kappa$ were \pm 0.05 throughout.
Table 3 presents reported intakes of selected micronutrients by the Young Hearts cohort at adolescence and at young adulthood. Changes in median micronutrient densities $\left(\mathrm{mg} \mathrm{MJ}^{-1}\right.$ or $\mu \mathrm{g} \mathrm{MJ}^{-1}$ ) of the males' diets were inconsistent over time. On the other hand, the males' diets became more nutrient-dense with respect to thiamin, vitamin $\mathrm{B}_{6}$, total folate, vitamins $\mathrm{C}$ and $\mathrm{D}$ (all $P<0.001$ ), whereas calcium $(P<0.05)$ and vitamin A $(P<0.001)$ densities fell with increasing age. No other significant changes in micronutrient densities were observed in the males' diets. The females' diets also became more nutrientdense with respect to thiamin, vitamin $\mathrm{B}_{6}$, total folate (all $P<0.001)$, vitamin $\mathrm{C}(P<0.01)$ and vitamin $\mathrm{D}(P<0.05)$. On the other hand, calcium $\left(\mathrm{mgday}^{-1}\right)$ and vitamin $\mathrm{A}$ $\left(\mu \mathrm{gday}^{-1}\right.$ ) intakes did not change during this period. In contrast to the males' diets, the median intakes of riboflavin $\left(\mathrm{mg} \mathrm{MJ}^{-1}\right)$ by females increased over time $(P<0.001)$. The shortfall in median iron $\left(\mathrm{mg} \mathrm{MJ}^{-1}\right)$ intakes relative to the Estimated Average Requirement (EAR) ${ }^{15}$ reported by the females was substantial both at adolescence $(-16.3 \%)$ and young adulthood ( $-14.7 \%)$. Moreover, median intakes of vitamin $\mathrm{B}_{6}\left(\mathrm{mg} \mathrm{MJ}^{-1}\right)$ and total folate $\left(\mu \mathrm{g} \mathrm{MJ}^{-1}\right)$ reported by the females were lower than the $\operatorname{EAR}^{15}$ at age 15 years $(-4.9 \%$ and $-18.8 \%$, respectively). Median intakes of all other micronutrients exceeded the EAR when expressed in terms of nutrient density.

The weighted $\kappa$ values obtained for the micronutrient intakes are summarised in Table 4. At the individual level, micronutrient intakes exhibited only poor to fair tracking during the study period. For intakes of vitamin A ( $\mu \mathrm{g}$ $R E$ day $^{-1}$, where RE is retinol equivalents) a fair degree of tracking was observed for both males and females ( $\kappa=0.25$ and 0.27 , respectively). Intakes of calcium $\left(\mathrm{mg} \mathrm{day}^{-1}\right)$ and riboflavin $\left(\mathrm{mg} \mathrm{day}^{-1}\right)$ exhibited a fair degree of tracking for males, but not for females $(\kappa=0.25$ and 0.26 vs. 0.18 and 0.20 , respectively). In contrast to the poor tracking of iron $(\kappa=0.10)$ and thiamin $(\kappa=0.14)$ in the males, a fair degree of tracking was observed for intakes of these micronutrients in females $(\kappa=0.23$ and 0.24 , respectively). In terms of nutrient density, a fair degree of tracking continued to be observed for vitamin A $\left(\mu \mathrm{gREMJ}{ }^{-1}\right)$ in both males and females $(\kappa=0.21$ and 0.24 , respectively). Poor tracking was observed for males' intakes of calcium $\left(\mathrm{mg} \mathrm{MJ}^{-1}\right)$ and folate $\left(\mu \mathrm{g} \mathrm{MJ}^{-1}\right)$ ( $\kappa=0.20$ and 0.10 , respectively), but in females the degree of tracking was marginally stronger $(\kappa=0.27$ and 0.21 , respectively). When adjusted for EI, intakes of iron, thiamin, riboflavin, vitamin $\mathrm{B}_{6}$, vitamin $\mathrm{C}$ and vitamin $\mathrm{D}$ exhibited only poor tracking in both sexes.

\section{Discussion}

Given the accumulating evidence of the link between nutrient intake and various chronic diseases, it seems prudent to undertake longitudinal studies to investigate the stability of nutrient intakes over time. To date, the 
Table 3 Intakes of selected micronutrients in the diets of the Young Hearts cohort at adolescence (age 15 years) and at young adulthood

\begin{tabular}{|c|c|c|c|c|c|c|c|c|c|}
\hline & & \multicolumn{4}{|c|}{ Males $(n=245)$} & \multicolumn{4}{|c|}{ Females $(n=231)$} \\
\hline & & \multicolumn{2}{|c|}{ Adolescence } & \multicolumn{2}{|c|}{ Young adulthood } & \multicolumn{2}{|c|}{ Adolescence } & \multicolumn{2}{|c|}{ Young adulthood } \\
\hline & & Median & $\left(P_{25}, P_{75}\right)$ & Median & $\left(P_{25}, P_{75}\right)$ & Median & $\left(P_{25}, P_{75}\right)$ & Median & $\left(P_{25}, P_{75}\right)$ \\
\hline \multirow[t]{2}{*}{ Iron } & $\left(\mathrm{mg} \mathrm{day}^{-1}\right)$ & 13.9 & $(11.7,16.8)$ & 12.8 & $(10.4,15.9)^{\star \star}$ & 10.2 & (8.4. 12.2) & 9.7 & $(8.0,11.7)$ \\
\hline & $\left(\mathrm{mg} \mathrm{MJ}^{-1} \mathrm{day}^{-1}\right)$ & 1.05 & $(0.93,1.18)$ & 1.01 & $(0.86,1.17)$ & 1.08 & $(0.99,1.20)$ & 1.20 & $(1.03,1.42)^{\star * *}$ \\
\hline \multirow[t]{2}{*}{ Calcium } & $\left(\mathrm{mg} \mathrm{day}^{-1}\right)$ & 1152 & $(939,1502)$ & 1101 & $(825,1407)^{\star \star}$ & 769 & $(600,972)$ & 683 & $(544,901)^{\star \star \star}$ \\
\hline & $\left(\mathrm{mg} \mathrm{MJ}^{-1} \mathrm{day}^{-1}\right)$ & 90.2 & $(73.8,105.9)$ & 86.2 & $(67.2,104.2)^{\star}$ & 85.7 & $(68.5,105.8)$ & 86.6 & $(69.1,105.5)$ \\
\hline \multirow[t]{2}{*}{ Thiamin } & $\left(\mathrm{mg} \mathrm{day}^{-1}\right)$ & 1.75 & $(1.41,2.13)$ & 1.89 & $(1.54,2.48)^{\star \star}$ & 1.10 & $(0.91,1.40)$ & 1.34 & $(1.07,1.71)^{\star \star \star}$ \\
\hline & $\left(\mathrm{mg} \mathrm{MJ}^{-1} \mathrm{day}^{-1}\right)$ & 0.14 & $(0.11,0.16)$ & 0.15 & $(0.13,0.18)^{\star \star \star}$ & 0.12 & $(0.10,0.15)$ & 0.17 & $(0.14,0.21)^{\star \star \star}$ \\
\hline \multirow[t]{2}{*}{ Riboflavin } & $\left(\mathrm{mg} \mathrm{day}^{-1}\right)$ & 2.27 & $(1.66,2.86)$ & 2.23 & $(1.77,2.77)$ & 1.28 & $(0.96,1.71)$ & 1.33 & $(0.94,1.77)$ \\
\hline & $\left(\mathrm{mg} \mathrm{MJ}^{-1} \mathrm{day}^{-1}\right)$ & 0.17 & $(0.13,0.22)$ & 0.18 & $(0.14,0.22)$ & 0.14 & $(0.11,0.18)$ & 0.16 & $(0.13,0.21)^{\star \star \star}$ \\
\hline \multirow[t]{2}{*}{ Vitamin $\mathrm{B}_{6}$} & $\left(\mathrm{mg} \mathrm{day}^{-1}\right)$ & 1.82 & $(1.55,2.16)$ & 3.33 & $(2.59,4.19)^{\star \star \star}$ & 1.29 & $(1.07,1.54)$ & 2.06 & $(1.66,2.52)^{\star \star \star}$ \\
\hline & $\left(\mathrm{mg} \mathrm{MJ}^{-1} \mathrm{day}^{-1}\right)$ & 0.14 & $(0.12,0.16)$ & 0.27 & $(0.22,0.31)^{\star \star \star}$ & 0.14 & $(0.13,0.16)$ & 0.25 & $(0.21,0.30)^{* * *}$ \\
\hline \multirow[t]{2}{*}{ Total folate } & $\left(\mu\right.$ g day $\left.^{-1}\right)$ & 169 & $(139,216)$ & 369 & $(285,471)^{\star \star \star}$ & 126 & $(103,161)$ & 212 & $(159,273)^{\star \star \star}$ \\
\hline & $\left(\mu \mathrm{gJ}^{-1} \mathrm{day}^{-1}\right)$ & 12.8 & $(10.6,15.2)$ & 29.1 & $(23.5,35.9)^{\star \star \star}$ & 13.8 & $(11.6,17.7)$ & 26.4 & $(20.8,32.5)^{\star \star \star}$ \\
\hline \multirow[t]{2}{*}{ Vitamin A } & $\left(\mu \mathrm{g} R \mathrm{day}^{-1}\right)$ & 804 & $(581,1082)$ & 690 & $(493,952)^{\star \star \star}$ & 599 & $(447,804)$ & 538 & $(390,690)^{\star \star \star}$ \\
\hline & $\left(\mu \mathrm{g} R \mathrm{MJ}^{-1}\right.$ day $\left.^{-1}\right)$ & 60.5 & $(47.6,81.1)$ & 55.1 & $(38.5,71.8)^{\star \star \star}$ & 66.8 & $(49.1,88.6)$ & 66.4 & $(48.8,82.5)$ \\
\hline \multirow[t]{2}{*}{ Vitamin C } & $\left(\mathrm{mg} \mathrm{day}^{-1}\right)$ & 74.6 & $(50.1,102.3)$ & 83.0 & $(54.5,125.0)^{\star \star}$ & 70.3 & $(42.1,114.2)$ & 73.0 & $(44.8,115.3)$ \\
\hline & $\left(\mathrm{mg} \mathrm{MJ}^{-1} \mathrm{day}^{-1}\right)$ & 5.77 & $(3.83,7.96)$ & 6.40 & $(4.37,9.69)^{\star \star \star}$ & 7.53 & $(4.57,12.29)$ & 8.70 & $(5.45,12.89)^{\star \star *}$ \\
\hline \multirow[t]{2}{*}{ Vitamin D } & $\left(\mu\right.$ g day $\left.^{-1}\right)$ & 1.38 & $(0.64,2.63)$ & 1.85 & $(1.27,2.97)^{\star \star \star}$ & 1.26 & $(0.65,2.33)$ & 1.47 & $(0.91,2.05)$ \\
\hline & $\left(\mu \mathrm{g} \mathrm{MJ}^{-1} \mathrm{day}^{-1}\right)$ & 0.10 & $(0.05,0.21)$ & 0.15 & $(0.10,0.22)^{\star \star \star}$ & 0.14 & $(0.07,0.25)$ & 0.18 & $(0.11,0.27)^{\star}$ \\
\hline
\end{tabular}

$\mathrm{P}_{25}$ - 25th percentile; $\mathrm{P}_{75}-75$ th percentile; $\mathrm{RE}$ - retinol equivalents.

Wilcoxon matched-pairs signed-ranks test used to test for significant differences: ${ }^{\star} P<0.05,{ }^{\star \star} P<0.01,{ }^{\star \star \star} P<0.001$ compared with median intake by group at age 15 years. 
Table 4 Tracking of micronutrient intakes as estimated by weighted kappa values $(\kappa)$

\begin{tabular}{|c|c|c|c|c|c|}
\hline & & & $7=245)$ & & $(n=231)$ \\
\hline & & $\kappa$ & $(95 \% \mathrm{Cl})$ & $\kappa$ & $(95 \% \mathrm{Cl})$ \\
\hline Iron & $(\mathrm{mg})$ & 0.10 & $(0.00,0.20)$ & 0.23 & $(0.13,0.33)$ \\
\hline & $\left(\mathrm{mg} \mathrm{MJ}^{-1}\right)$ & 0.12 & $(0.01,0.22)$ & 0.13 & $(0.03,0.24)$ \\
\hline Calcium & (mg) & 0.25 & $(0.15,0.34)$ & 0.18 & $(0.08,0.28)$ \\
\hline & $\left(\mathrm{mg} \mathrm{MJ}^{-1}\right)$ & 0.20 & $(0.10,0.30)$ & 0.27 & $(0.17,0.37)$ \\
\hline Thiamin & (mg) & 0.14 & $(0.03,0.24)$ & 0.24 & $(0.14,0.34)$ \\
\hline & $\left(\mathrm{mg} \mathrm{MJ}^{-1}\right)$ & 0.07 & $(-0.03,0.17)$ & 0.17 & $(0.07,0.28)$ \\
\hline Riboflavin & (mg) & 0.26 & $(0.16,0.35)$ & 0.20 & $(0.09,0.30)$ \\
\hline & $\left(\mathrm{mg} \mathrm{MJ}^{-1}\right)$ & 0.14 & $(0.04,0.24)$ & 0.19 & $(0.08,0.29)$ \\
\hline Vitamin $\mathrm{B}_{6}$ & (mg) & 0.12 & $(0.02,0.22)$ & 0.13 & $(0.03,0.23)$ \\
\hline & $\left(\mathrm{mg} \mathrm{MJ}^{-1}\right)$ & -0.01 & $(-0.11,0.09)$ & 0.13 & $(0.03,0.24)$ \\
\hline Total folate & $(\mu \mathrm{g})$ & 0.15 & $(0.05,0.26)$ & 0.12 & $(0.02,0.23)$ \\
\hline & $\left(\mu \mathrm{gMJ}^{-1}\right)$ & 0.10 & $(0.00,0.20)$ & 0.21 & $(0.11,0.31)$ \\
\hline Vitamin A & ( $\mu \mathrm{g} R E)$ & 0.25 & $(0.15,0.34)$ & 0.27 & $(0.17,0.37)$ \\
\hline & $\left(\mu \mathrm{g} R \mathrm{MJ}^{-1}\right)$ & 0.21 & $(0.11,0.31)$ & 0.24 & $(0.14,0.34)$ \\
\hline Vitamin C & (mg) & 0.16 & $(0.06,0.26)$ & 0.20 & $(0.09,0.30)$ \\
\hline & $\left(\mathrm{mg} \mathrm{MJ}^{-1}\right)$ & 0.19 & $(0.09,0.28)$ & 0.20 & $(0.10,0.31)$ \\
\hline Vitamin D & $(\mu \mathrm{g})$ & 0.06 & $(-0.04,0.16)$ & 0.06 & $(-0.04,0.17)$ \\
\hline & $\left(\mu g \mathrm{MJ}^{-1}\right)$ & 0.05 & $(-0.05,0.15)$ & 0.03 & $(-0.08,0.13)$ \\
\hline
\end{tabular}

$\mathrm{Cl}$ - confidence interval; RE - retinol equivalents.

$\kappa$ values were calculated as described in the Methodology; standard errors for $\kappa$ were \pm 0.05 throughout.

evidence for tracking of nutrient intakes from adolescence to young adulthood has been somewhat scarce and inconsistent. Furthermore, methodological differences between dietary data collection, time period lapses between sampling periods and methods used for the calculation of tracking coefficients make it difficult to meaningfully compare different datasets.

The main criteria used for the selection of a suitable method for the collection of dietary data were that the method should be relatively quick to undertake, suitable for surveying large groups, and involve a low respondent burden (particularly apt when studying these age groups). Although the diet history used in this study is not a standardised technique, particular care was taken to ensure that the same protocol was followed at each sampling time point. As this method measures only memory and perception of usual diet, it is subjective and therefore may be particularly vulnerable to exaggeration of 'good' foods and underestimation of foods perceived as 'bad'. As a result it is conceivable that nutrient intakes may have been subject to misrepresentation but this is impossible to quantify in this study. Another possible source of bias is that the diet history method is easier to undertake in those with regular eating behaviours and, given the irregularity of adolescent eating behaviours, it may be more difficult for respondents in the age groups studied to recall foods eaten. The choice of any survey method will always be a compromise between subject burden and likely inaccuracies in dietary reporting. Thus since the method chosen for the baseline study was considered the most suitable at that time, it would have been inappropriate to change it for the follow-up survey.

Dietary surveys usually report a wide range of EI with extremes of intakes that are unlikely to reflect habitual intake and such under- and overreported intakes may distort the ranking of subjects ${ }^{16}$. Varying levels of underand overreporting of intakes are apparent in the present study population. Using the Goldberg et al. ${ }^{17}$ cut-off of 1.18 for $\mathrm{EI} / \mathrm{BMR}_{\mathrm{est}}$, it is apparent that underreporting at the individual level increases with increasing age in the present cohort, with $2.4 \%$ of males compared with $18.2 \%$ of females at adolescence being classified as 'underreporters', rising to $11.0 \%$ and $29.9 \%$ respectively at young adulthood. It is thus highly likely that the increase in underreporting has attenuated the tracking of nutrient intakes within the cohort. Using a cut-off of 2.5 for EI/ $\mathrm{BMR}_{\text {est }}$ to define overreporters ${ }^{12}$, overall levels of overreporting decreased over time, although males continued to overreport their intakes compared with females $(7.8 \%$ vs. $1.7 \%$, respectively).

Various statistical methods are employed to assess whether dietary intakes track over time. In the present study, a method based on ranking observations was chosen to determine the extent of tracking of intakes. This was selected in preference to a method based on actual intakes because of its simplicity and its ability to show the rates of transitions between the tertile classes ${ }^{6}$. Thus, this method provides a broad picture of the relative changes in intake from adolescence into young adulthood. A fair degree of tracking was observed in the present study for EI (adjusted for body weight) between adolescence and young adulthood in contrast to the overall poor tracking coefficients $(\kappa<0.20)$ observed for macronutrient intakes; these findings largely reflect the tracking patterns in this cohort between age 12 and 15 years ${ }^{6}$. In contrast, some differences in the tracking patterns of micronutrient intakes were observed. 
A recent analysis by Black and Cole ${ }^{18}$ of seven UK-based studies highlighted subject-specific bias in dietary reporting with repeated dietary assessment (with the same measurement method or with different methods). Such subjectspecific bias supports the view that people who misreport dietary intakes in one survey are likely to do so (and probably to the same level of magnitude) on repeat measurement and also suggests that the extremes of intake are likely to maintain their ranking (lowest or highest tertile) within a population over time. Thus, under- and overreporting by subjects in the present study may provide one explanation for the lack of tracking of EI and energyadjusted nutrient intakes. Furthermore, other factors (such as changes over time in body size, physical activity, attitudes, knowledge, etc.) may be important confounders when assessing the extent of tracking of intakes. Indeed, attempts to adjust for body size (e.g. EI per kg body weight) or EI (e.g. nutrient intakes as \%EI) may introduce further bias and again help explain the overall poor tracking coefficients observed.

The only other comparable study of tracking in terms of the ages investigated and the dietary methods employed was the Amsterdam Growth and Health Longitudinal Study. This study has periodically assessed nutrient intake using the diet history method in a group of 73 males and 91 females (aged 13-17 years at baseline) through to adulthood (age 27 years) ${ }^{19}$. Post et $a l^{4}{ }^{4}$ reported increases in EI between ages 13 and 21 years for males and a more stable EI pattern over time for females between ages 13 and 21 years, which is in contrast to the stable EI in males but decreasing EI in females in the present study. The former study also observed that males had significantly higher $(+25 \%)$ EI than females over the whole age range (age 13-33 years) studied, which is largely comparable with findings in the present study $(31-35 \%)$. When expressed relative to body weight, patterns of EI in the present study are comparable with those of Post et al. ${ }^{4}$ as are patterns of protein and fat intakes. Fair to moderate tracking of calcium intakes in males and females over the same 14-year period has also been described for this cohort $^{19}$. More recently Post et al. ${ }^{4}$ observed relatively low but significant stability coefficients for tracking of macro- and micronutrients between adolescence and adulthood and concluded that dietary intake between adolescence and adulthood was changeable.

Dunn et $a l^{5}$ concluded that despite considerable changes in lifestyle between age 18 and 30 years, individuals do tend to remain within broad categories of ranking. In contrast, in a younger cohort (12 to 18 years), Cusatis et al. ${ }^{3}$ observed varying patterns of dietary intakes over time in females and concluded that nutrient intake patterns did not track strongly during this period of adolescence.

Stronger tracking coefficients for dietary intake have been reported over shorter periods and in younger age groups $^{20-23}$. As individuals move from childhood through adolescence and on to young adulthood, it is possible that increasing autonomy and food choice is mirrored in changes to patterns of dietary intake. It is possible that, between adolescence and young adulthood, the significant lifestyle changes that these individuals experience, such as starting new careers or families, has a greater impact on dietary intakes than has been previously predicted. The substantial drift of subjects between the low, medium and high classes of EI and macronutrient intake between adolescence and young adulthood in the present study would support this case. Moreover, these data suggest that individual dietary patterns exhibited at 15 years of age are unlikely to be predictive of dietary intakes at young adulthood.

Similar analysis to that outlined in the present paper was undertaken for the subjects at age 12 years and subsequently at young adulthood. These data (not presented) suggest that tracking of intakes between these time points was even weaker, although this may also reflect the smaller size of the analysis cohort ( $n=135$ males, $n=119$ females). In contrast to poor to fair tracking observed for dietary intakes, it is noteworthy that considerably stronger tracking coefficients were observed for anthropometric measurements (weight, BMI, body fatness) in this cohort between age 12 and 15 years $^{24}$, similar to the tracking observed for these measures between age 15 and 20-25 years (data not presented). This finding has been noted in other surveys ${ }^{25}$.

The results of the present study indicate that, in a group of adolescents from Northern Ireland, dietary intakes at age 15 years did not appear to predict dietary intakes at young adulthood. That stabilising of food habits did not appear to occur during this period of life possibly reflects that this is a period within the life cycle when patterns of dietary intake are impacted by substantial lifestyle changes. However, given the extent of misreporting in many dietary surveys, it remains unclear whether the apparent lack of tracking observed in many studies is real, making it almost impossible to correlate nutrient intakes over time with the eventual development of disease.

\section{Acknowledgements}

The first two phases of the Young Hearts Project (YH1 and YH2) were supported by the Northern Ireland Chest, Heart and Stroke Association. The Project Team would also like to thank the British Heart Foundation and the Wellcome Trust for their support of YH3. The authors would like to thank the subjects who participated in the project, and all fieldworkers who collected the dietary data (Hilary Morrison, Elizabeth Archer, Siobhan Higgins, Dara Morgan, Charlotte Neville and Meabh McGuinness).

\section{References}

1 Kelder SH, Perry CL, Klepp K-I, Lytle LL. Longitudinal tracking of adolescent smoking, physical activity and food 
choice behaviors. American Journal of Public Health 1994; 84: 1121-6.

2 Twisk JWR, van Mechelen W, Kemper HCG, Post GB. The relation between 'long-term exposure' to lifestyle during youth and young adulthood and risk factors for cardiovascular disease at adult age. Journal of Adolescent Health 1997; 20: 309-19.

3 Cusatis DC, Chinchilli VM, Johnson-Rollings N, Kieselhorst $\mathrm{K}$, Stallings VA, Llyod T. Longitudinal nutrient intake patterns of US adolescent women: the Penn State Young Women's Health Study. Journal of Adolescent Health 2000; 26: 194-204.

4 Post GB, deVente W, Kemper HCG, Twisk JWR. Longitudinal trends in and tracking of energy and nutrient intake over 20 years in a Dutch cohort of men and women between 13 and 33 years of age: the Amsterdam growth and health longitudinal study. British Journal of Nutrition 2001; 85: 375-85.

5 Dunn JE, Liu K, Greenland P, Hilner JE, Jacobs DR Jr. Sevenyear tracking of dietary factors in young adults: the CARDIA study. American Journal of Preventive Medicine 2000; 18: $38-45$.

6 Robson PJ, Gallagher AM, Livingstone MBE, Cran GW, Strain JJ, Savage JM, et al. Tracking of nutrient in adolescence: the experiences of the Young Hearts Project, Northern Ireland. British Journal of Nutrition 2000; 84: 541-8.

7 Gallagher AM, Savage JM, Murray LJ, Davey Smith G, Young IS, Robson PJ, et al. A longitudinal study through adolescence to adulthood: the Young Hearts Project, Northern Ireland. Public Health 2002; 116: 332-40.

8 Boreham C, Savage JM, Primrose D, Cran G, Strain J. Coronary risk factors in schoolchildren. Archives of Disease in Childhood 1993; 68: 182-6.

9 Durnin JVG, Rahaman MM. The assessment of the amount of fat in the human body by measurements of skinfold thickness. British Journal of Nutrition 1967; 21: 681-9.

10 Tanner JM. Growth at Adolescence. Oxford: Blackwell, 1962.

11 Van Staveren WA, de Boer JO, Burema J. Validity and reproducibility of a dietary history method estimating the usual food intake during one month. American Journal of Clinical Nutrition 1985; 42: 554-9.

12 Strain JJ, Robson PJ, Livingstone MBE, Primrose ED, Savage $\mathrm{JM}$, Cran GW, et al. Estimates of food and macronutrient intake in a random sample of Northern Ireland adolescents. British Journal of Nutrition 1994; 72: 343-52.

13 Schofield WN, Schofield C, James WPT. Basal metabolic rate - review and prediction. Human Nutrition. Clinical Nutrition 1985; 39C(Suppl. 1): 1-96.
14 Altman DG. Practical Studies for Medical Research. London: Chapman \& Hall, 1991; 404-7.

15 Department of Health. Dietary Reference Values for Food Energy and Nutrients for the United Kingdom. London: HM Stationery Office, 1991.

16 Livingstone MBE, Black AE. Markers of the validity of reported energy intake. Journal of Nutriiton 2003; 133: 895S-920S.

17 Goldberg GR, Black AE, Jebb SA, Cole TJ, Murgatroyd PR, Coward WA, et al. Critical evaluation of energy intake data using fundamental principles of energy physiology: 1. Derivation of cut-off limits to identify under-recording. European Journal of Clinical Nutrition 1991; 45: 569-81.

18 Black AE, Cole TJ. Biased over- or under-reporting is characteristic of individuals whether over time or by different assessment methods. Journal of the American Dietetic Association 2001; 101: 70-80.

19 Welten DC, Kemper HCG, Post GB, Van Staveren WA, Twisk JWR. Longitudinal development and tracking of calcium and dairy intake from teenager to adult. European Journal of Clinical Nutrition 1997; 51: 612-8.

20 Stein AD, Shea S, Basch CE, Contento IR, Zybert P. Variability and tracking of nutrient intakes of preschool children based on multiple administrations of the 24-hour dietary recall. American Journal of Epidemiology 1991; 134: 1427-37.

21 Singer MR, Moore LL, Garrahie EJ, Ellison RC. The tracking of nutrient intake in young children: the Framingham Children's Study. American Journal of Public Health 1995; 85: $1673-7$.

22 Wang Y, Bentley ME, Zhai F, Popkin BM. Tracking of dietary intake patterns of Chinese from childhood to adolescence over a six-year follow-up period. Journal of Nutrition 2002; 132: $430-8$.

23 Zive MM, Berry CC, Sallis JF, Frank GC, Nader PR. Tracking dietary intake in white and Mexican-American children from age 4 to 12 years. Journal of the American Dietetic Association 2002; 102: 683-9.

24 Robson PJ, Neville CE, Twisk J, Strain JJ, Livingstone MBE, McGuinness $\mathrm{M}$, et al. Tracking of body composition from adolescence to early adulthood: the Young Hearts Project. Annals of Nutrition E Metabolism 2001; 45(Suppl. 1): 337.

25 Power C, Lake JK, Cole TJ. Body mass index and height from childhood to adulthood in the 1958 British born cohort. American Journal of Clinical Nutrition 1997; 66: $1094-101$. 